Egg Parasitoids in Agroecosystems with Emphasis on Trichogramma 


\section{Progress in Biological Control}

Volume 9

Published:

Volume 1

H.M.T. Hokkanen and A.E. Hajek (eds.):

Environmental Impacts of Microbial Insecticides - Need and Methods for Risk

Assessment. 2004

ISBN 978-1-4020-0813-9

Volume 2

J. Eilenberg and H.M.T. Hokkanen (eds.):

An Ecological and Societal Approach to Biological Control. 2007

ISBN 978-1-4020-4320-8

Volume 3

J. Brodeur and G. Boivin (eds.):

Trophic and Guild Interactions in Biological Control. 2006

ISBN 978-1-4020-4766-4

Volume 4

J. Gould, K. Hoelmer and J. Goolsby (eds.):

Classical Biological Control of Bemisia tabaci in the United States. 2008

ISBN 978-1-4020-6739-6

Volume 5

J. Romeis, A.M. Shelton and G. Kennedy (eds.):

Integration of Insect-Resistant Genetically Modified Crops within IPM Programs.

2008

Volume 6

HB ISBN 978-1-4020-8372-3; PB ISBN 978-1-4020-8459-1

A.E. Hajek, T.R. Glare and M. O'Callaghan (eds.):

Use of Microbes for Control and Eradication of Invasive Arthropods. 2008

ISBN: 978-1-4020-8559-8

Volume 7

H.M.T. Hokkanen (ed.):

Relationships of Natural Enemies and Non-Prey Foods. 2008

ISBN: 978-1-4020-9234-3

Volume 8

S.S. Gnanamanickam:

Biological Control of Rice Diseases

ISBN: 978-90-481-2464-0

For further volumes:

http://www.springer.com/series/6417 
Fernando L. Cônsoli · José R.P. Parra · Roberto A. Zucchi Editors

Egg Parasitoids in Agroecosystems with Emphasis on Trichogramma

照 Springer 
Editors

Dr. Fernando L. Cônsoli

Universidade de São Paulo

ESALQ

Departamento de Entomologia

e Acarologia

Avenida Pádua Dias 11

13418-900, Piracicaba, São Paulo

Brazil

fconsoli@esalq.usp.br

Dr. Roberto A. Zucchi

Universidade de São Paulo

ESALQ

Departamento de Entomologia

e Acarologia

Avenida Pádua Dias 11

13418-900, Piracicaba, São Paulo

Brazil

razucchi@esalq.usp.br
Dr. José R.P. Parra

Universidade de São Paulo

ESALQ

Departamento de Entomologia

e Acarologia

Avenida Pádua Dias 11

13418-900, Piracicaba, São Paulo

Brazil

jrpparra@esalq.usp.br

ISBN 978-1-4020-9109-4

e-ISBN 978-1-4020-9110-0

DOI 10.1007/978-1-4020-9110-0

Springer Dordrecht Heidelberg London New York

Library of Congress Control Number: 2010935670

(C) Springer Science+Business Media B.V. 2010

No part of this work may be reproduced, stored in a retrieval system, or transmitted in any form or by any means, electronic, mechanical, photocopying, microfilming, recording or otherwise, without written permission from the Publisher, with the exception of any material supplied specifically for the purpose of being entered and executed on a computer system, for exclusive use by the purchaser of the work.

Cover pictures: Pictures on the cover are credited to BSc Heraldo Negri de Oliveira (ESALQ/USP Departamento de Entomologia e Acarologia, Piracicaba, Brazil)

Printed on acid-free paper

Springer is part of Springer Science+Business Media (www.springer.com) 


\section{Contents}

1 Reproduction and Immature Development of Egg Parasitoids . . . 1 Guy Boivin

2 Nutritional Ecology of Insect Egg Parasitoids . . . . . . . . . . . . 25 S. Bradleigh Vinson

3 Antennal Structures Used in Communication by Egg Parasitoids . 57 Roberto Romani, Nunzio Isidoro, and Ferdinando Bin

4 Host Searching by Egg Parasitoids: Exploitation of Host Chemical Cues . . . . . . . . . . . . . . . . . . . . . . . . . 97

Stefano Colazza, Ezio Peri, Gianandrea Salerno, and Eric Conti

5 Genetics of the Behavioral Ecology of Egg Parasitoids . . . . . . . 149 Eric Wajnberg

6 Sex Ratio Modulators of Egg Parasitoids . . . . . . . . . . . . . . . 167 James E. Russell and Richard Stouthamer

7 Systematics of the Trichogrammatidae (Hymenoptera:

Chalcidoidea) with a Focus on the Genera Attacking Lepidoptera . Ranyse B. Querino, Roberto A. Zucchi, and John D. Pinto

8 Diversity and Hosts of Trichogramma in the New World, with Emphasis in South America

Roberto A. Zucchi, Ranyse B. Querino, and Renata C. Monteiro

9 Species Diversity and Host Associations of Trichogramma

Andrew Polaszek

10 Mass Rearing of Egg Parasitoids for Biological Control Programs . 267 José Roberto Postali Parra

11 In Vitro Rearing of Egg Parasitoids . . . . . . . . . . . . . . . . . . 293 Fernando L. Cônsoli and Simon Grenier

12 Quality Control of Mass Reared Egg Parasitoids . . . . . . . . . . 315 Joop C. van Lenteren and Franz Bigler 
13 Biological Control with Egg Parasitoids other than

Trichogramma - the Citrus and Grape Cases . . . . . . . . . . . . 341

Jorge E. Peña, Josep A. Jacas, Serguei Triapitsyn,

Bryan J. Ulmer, and R.E. Duncan

14 Egg Parasitoids Commercialization in the New World . . . . . . . 373 José Roberto Postali Parra

15 Egg Parasitoids in Biological Control and Integrated Pest Management . . . . . . . . . . . . . . . . . . . . . . 389 Nick Mills

16 Risk Assessment and Non-target Effects of Egg Parasitoids in Biological Control . . . . . . . . . . . . . . . . . . . . . . . . . . 413 Franz Bigler, Dirk Babendreier, and Joop C. van Lenteren

17 Genetically Modified Crops and Biological Control with Egg Parasitoids . . . . . . . . . . . . . . . . . . . . . . . . . . 443 Julio S. Bernal

Subject Index . . . . . . . . . . . . . . . . . . . . . . . . . . . . . . . 467

Natural Enemy Species Index . . . . . . . . . . . . . . . . . . . . . 473 


\section{Contributors}

Dirk Babendreier CABI Europe, Rue des Grillons 1, 2800 Delémont, Switzerland, d.babendreier@cabi.org

Julio S Bernal Department of Entomology, Texas A\&M University, College Station, TX 77843-2475, USA, juliobernal@ tamu.edu

Franz Bigler Agroscope Reckenholz-Taenikon Research Station ART, Reckenholzstr. 191, 8046 Zurich, Switzerland, franz.bigler@art.admin.ch

Ferdinando Bin Department of Scienze Agrarie e Ambientali, Faculty of Agriculture, University of Perugia, Borgo XX Giugno 74, 06121, Perugia, Italy, fbin@unipg.it

Guy Boivin Centre de Recherche et de Développement, Agriculture et Agroalimentaire Canada, 430 Boul. Gouin, St-Jean-sur-Richelieu, QC, Canada J3B 3E6, boiving@agr.gc.ca

Stefano Colazza Department of S.En.Fi.Mi.Zo., Section of Acarology, Entomology and Zoology, University of Palermo, Viale delle Scienze 13, 90128, Palermo, Italy, colazza@unipa.it

Fernando L. Cônsoli Laboratório de Interações em Insetos, Departamento de Entomologia e Acarologia, ESALQ/USP, Av. Pádua Dias 11, 13418-900, Piracicaba, São Paulo, Brazil, fconsoli@esalq.usp.br

Eric Conti Department of Scienze Agrarie e Ambientali, Faculty of Agriculture, University of Perugia, Borgo XX Giugno 74, 06121, Perugia, Italy, econti@unipg.it

R.E. Duncan Department of Entomology and Nematology, Tropical Research and Education Center, University of Florida, Homestead, FL 33031, USA, red@ifas.ufl.edu

Simon Grenier UMR INRA/INSA, Biologie Fonctionnelle Insectes et Interactions, Villeurbanne, France, simon-grenier@orange.fr 
Nunzio Isidoro Faculty of Agriculture, Department of Scienze Ambientali e delle Produzioni Vegetali, Politechnic University of Marche, Via Brecce Bianche, 60131, Ancona, Italy, n.isidoro@univpm.it

Josep A. Jacas Departament de Ciències Agràries i del Medi Natural, Universitat Jaume I, E-12071 Castello de la Plana, Spain, jacas@camn.uji.es

Joop C. van Lenteren Laboratory of Entomology, Wageningen University, PO Box 8031, 6700EH Wageningen, The Netherlands, Joop.vanLenteren@wur.nl

Nick Mills Department of Environmental Science, Policy and Management, University of California, Berkeley, CA 94720-3114, USA, nmills@ berkeley.edu

Renata C. Monteiro Departamento Entomologia e Acarologia, ESALQ/USP, Av. Padua Dias 11, 13418-900 Piracicaba, São Paulo, Brazil, renatathrips@yahoo.com

José Roberto Postali Parra Departamento de Entomologia e Acarologia, ESALQ/USP, Av. Pádua Dias 11, 13418-900 Piracicaba, São Paulo, Brazil, jrpparra@esalq.usp.br

Jorge E. Peña Department of Entomology and Nematology, Tropical Research and Education Center, University of Florida, Homestead, FL 33031, USA, jepe@ifas.ufl.edu

Ezio Peri Department of S.En.Fi.Mi.Zo., section of Acarology, Entomology and Zoology, University of Palermo, Viale delle Scienze 13, 90128, Palermo, Italy

John D. Pinto Department of Entomology, University of California, Riverside, CA 92521, USA,jpinto@ucr.edu

Andrew Polaszek Natural History Museum, London, UK, ap@nhm.ac.uk

Ranyse B. Querino Embrapa Meio-Norte, Av. Duque de Caxias 5650, 64006-220 Teresina, Piauí, Brazil, ranyse@ cpamn.embrapa.br

Roberto Romani Department of Scienze Agrarie e Ambientali, Faculty of Agriculture, University of Perugia, Borgo XX Giugno 74, 06121, Perugia, Italy, rromani@unipg.it

James E. Russell Department of Biology, University of California, Riverside, CA 92521, USA, jeruss002@gmail.com

Gianandrea Salerno Department of Scienze Agrarie e Ambientali, Faculty of Agriculture, University of Perugia, Borgo XX Giugno 74, 06121, Perugia, Italy, Salerno@unipg.it

Richard Stouthamer Department of Biology, University of California, Riverside, CA 92521, USA, richard.stouthamer@ucr.edu

Serguei Triapitsyn Department of Entomology, University of California, Riverside, CA 92521, USA, serguei.triapitsyn@ucr.edu 
Bryan J. Ulmer Department of Entomology and Nematology, Tropical Research and Education Center, University of Florida, Homestead, FL 33031, USA

S. Bradleigh Vinson Texas A\&M University, College Station, TX 77843-2475, USA, bvinson@tamu.edu

Eric Wajnberg INRA - 400, Route des Chappes, BP 167 - 06903, Sophia Antipolis, Cedex, France, wajnberg@sophia.inra.fr

Roberto A. Zucchi Departamento Entomologia e Acarologia, ESALQ/USP, Av. Pádua Dias 11, 13418-900 Piracicaba, São Paulo, Brazil, razucchi@esalq.usp.br 